\title{
Stability of deep-bite correction: A systematic review
}

\author{
Greg J. Huang ${ }^{a,{ }^{*}}$, Steven B. Bates ${ }^{b}$, Ambre A. Ehlert ${ }^{b}$, Dean P. Whiting ${ }^{b}$, Stephanie S.-H. \\ Chen $^{\mathrm{C}}$, and Anne-Marie Bollen ${ }^{\mathrm{a}}$ \\ aDepartment of Orthodontics, University of Washington, Seattle, Washington \\ bUniversity of Washington School of Dentistry, Seattle, Washington \\ cPrivate Practice, Taipei, Taiwan
}

\begin{abstract}
Objectives-Deep bite occurs in about $15 \%$ to $20 \%$ of the US population. Currently, it is unknown which types of correction are most efficient or stable. The purpose of this systematic review was to investigate factors related to stability of deep-bite correction.

Materials and Methods-An electronic search of 4 databases was performed from January 1 , 1966 to June 27, 2012. Studies were considered for inclusion if they reported on deep bite samples that underwent orthodontic treatment in the permanent dentition. Records were required at the initial, posttreatment, and 1-year posttreatment times. Hand searching of reference lists of the included studies was performed. Data were abstracted using custom forms, and risk of bias was assessed using a modified Newcastle-Ottawa Scale.
\end{abstract}

Results-Twenty-six studies met the inclusion criteria. Most were case series, with considerable potential for bias. The significant heterogeneity of the studies precluded meta-analyses, and only descriptive statistics and stratified comparisons were reported. On average, patients underwent significant overbite improvement during treatment, and most of the correction was maintained long-term. Across all studies, the mean initial overbite, posttreatment overbite, and long-term overbite were 5.3, 2.6, and $3.4 \mathrm{~mm}$, respectively. Initial severity appeared to be related to longterm stability. However, this relationship was difficult to isolate from other factors. The length of follow-up did not appear to be related to the amount of relapse.

Conclusions-Although the quality of the current evidence is not high, patients with deep-bite malocclusion appear to undergo relatively successful treatment, and most of the correction appears to be stable.

\section{Keywords}

Deep bite; Deep overbite; Stability; Systematic review

\section{Introduction}

An anterior deep bite (or deep overbite) is defined as an increased vertical overlap between the upper and lower incisors. Depending on the definition of "increased," the reported prevalence of deep bite ranges from $11.8 \%$ [1] to $36.7 \%$ [2]. A large cross-sectional study in the United States reported that $15 \%-20 \%$ of the population had overbite $\geq 5 \mathrm{~mm}$ [3], depending on the age range of interest. Extremely deep overbite can be associated with

\footnotetext{
(C) 2012 World Federation of Orthodontists.

*Corresponding author: Box 357446, Seattle, WA 98195. ghuang@u.washington.edu. .
} 
impingement of the palatal tissues, resulting in damage to the periodontium on the lingual surface of the maxillary incisors.

Many methods have been utilized to treat deep-bite malocclusions. They range from removable appliances to fixed appliances with or without orthognathic surgery. Although these treatments all reduce deep bites, it is unclear if some treatments are more efficient or effective than others. Additionally, it is unclear whether pretreatment severity, extractions of premolars, or differing methods of retention are related to long-term stability of deep-bite correction. Some systematic reviews have investigated intrusion of incisors [4] or treatment for Class II, Division 2 malocclusion [5], however, we are unaware of any systematic review that addresses long-term stability of deep-bite treatment. The purpose of this systematic review was to investigate stability of orthodontically corrected deep-bite malocclusions. Specifically, in patients with deep bite, are any patient or treatment parameters associated with better stability, as measured by long-term overbite?

\section{Materials and methods}

\subsection{Inclusion criteria}

The preferred reporting items for systematic reviews and meta-analyses guidelines were used as a reference for the conduct of this systematic review. The following selection criteria were established prior to the search:

- Study design - randomized clinical trials, cohort studies, case-control studies, and case series of 15 or more patients;

- Population - only human studies, with no restrictions on age or sex. Surgical studies were excluded, as were those involving patients with cleft palate or syndromes;

- Intervention - comprehensive orthodontic treatment in the permanent dentition to correct an anterior deep bite (mean initial overbite $>4 \mathrm{~mm}$.) Studies on early treatment without subsequent comprehensive treatment were excluded;

- Comparison - a nontreated control group, a different patient characteristic, or a different orthodontic treatment modality;

- Outcome - overbite at the end of treatment and at least 1 year after treatment. Patients could still be using retainers at the follow-up time.

\subsection{Search methods for identification of studies}

We obtained article citations from January 1, 1966 to June 27, 2012 through an electronic search of the following electronic databases: MEDLINE, Web of Science, EMBASE, and the Cochrane library. The search was conducted with the assistance of a senior librarian. Search strategies and key words are listed in Appendix A. No studies were excluded based on language of publication. Titles and abstracts were examined for inclusion by at least two investigators (SB, AE, DW, SC, AB, GH). Full-length articles were requested for all articles that passed the initial screening. The reference lists of the retrieved full articles were hand searched, and the complete text was obtained for any articles that were deemed to be potentially relevant. Each full-length article was assessed by two investigators for final inclusion/exclusion. In cases of disagreement, a third investigator was consulted, and a decision was made by consensus. Some authors were contacted for additional information. 


\subsection{Data extraction}

For each included article, two investigators performed independent data extraction (SB, AE, DW, SC, AB, GH), using a piloted, custom-designed data collection form. Study characteristics (study design, setting, methods, etc.) and sample characteristics (sample size, age, gender, molar classification, type of treatment, etc) were collected, as well as overbite measurements (mean and standard deviation) before and after treatment, and long-term. Disagreements were resolved by consensus.

\subsection{Statistical analyses}

Analyses were planned for factors such as initial overbite, molar classification, age, extraction, and retention methods based on mean values or proportions. Obviously, performance of these analyses was contingent on the results of the search and data extraction processes. Forest plots were planned if sufficient numbers of studies were encountered with relatively homogeneous characteristics and methods. Likewise, assessment of publication bias with funnel plots would be performed if possible.

\subsection{Assessment of methodological quality}

A quality analysis was done, loosely based on the Newcastle-Ottawa Quality Assessment Scale. In the "selection" domain, we assessed whether inclusion criteria were specified, and whether sampling was random or consecutive. In the "comparability" domain, we assessed sample size, as well as the use of stratified or multivariate analyses. In the "assessment" domain, we rated studies based on report of blinded assessment. One point was given for fulfillment of each of the following criteria: stated inclusion criteria, consecutive or random sampling, sample size $\mathbf{2 3 0}$, blinded assessment, and use of stratified or multivariate analyses. Studies were judged as having high, moderate, or low risk for bias based on their point total $(0-2=$ high risk, $3-4=$ moderate risk, and $5=$ low risk $)$.

\section{Results and discussion}

The electronic search identified 1369 citations, of which 271 duplicates were removed. Based on review of the titles and abstracts of the remaining 1098 articles by at least two investigators, 1050 were excluded from further consideration. Full text versions were requested for the remaining 48 articles, with final selection based on the consensus of at least two reviewers. Twenty-three articles were deemed eligible for final inclusion [6-28]. Hand searching of the reference lists of the included articles yielded another three articles that met the inclusion criteria [29-31], for a total of 26 included studies (Fig. 1). Data from one study [28] was supplemented with data from a thesis reporting on the same patients [32]. Excluded articles, with reasons, are provided in Appendix B [5,33-56].

The characteristics of the included studies are listed in Table 1. Of the 26 studies that were included in this systematic review, 22 were case series and 4 were retrospective cohort studies. One article was published in German, one article in Dutch, two simultaneously in German and English, and the rest in English. Most studies assessed adolescent patients treated with fixed appliances. Factors addressed in the studies included initial severity, molar classification, incisor angulation and intrusion, extraction status, age of treatment, different types of appliances or mechanics, retention methods, and length of follow-up. Data from subgroups reporting median values were excluded from further analysis. One study reported "corrected" overbite values for Class II patients, and these data also were excluded from further comparison [23]. An assessment of study characteristics indicated that 24 of 26 studies had a moderate to high risk of bias (Table 2). 
We considered performing meta-analyses for various parameters, specifically molar classification and extraction status. However, the considerable heterogeneity of the few studies with data amenable to meta-analyses did not allow for meaningful comparisons. Therefore, no forest plots or funnel plots were constructed. Due to the disparate nature of the studies, only simple descriptive and stratified comparisons are reported.

The mean initial overbite reported in the studies ranged from 4.0-7.6 mm (Table 1). The mean amount of correction, in millimeters, varied from $0.9-4.4 \mathrm{~mm}$. In percentages, the correction ranged from $18 \%-83 \%$. During the follow-up periods, which ranged from 1.214.7 years, the mean amount of relapse varied from $0-2.1 \mathrm{~mm}$, or $0 \%-82 \%$ of the overbite correction during treatment. Excluding the studies reporting median values [21,22] or corrected data [23], the mean values for initial, posttreatment, and long-term overbite were $5.3 \mathrm{~mm}, 2.6 \mathrm{~mm}$, and $3.4 \mathrm{~mm}$, respectively.

The studies were stratified based on molar classification and extraction status. Weighted averages for overbite and follow-up time were calculated for each group, based on the sample size. Graphs were constructed for each group using the weighted averages (Figs. 25). The graphs categorized by molar classification indicated that there were no large differences in the amount of correction or relapse when comparing patients who did and did not undergo extractions. The final overbite value in almost all categories was between 3 and $4 \mathrm{~mm}$.

In order to explore the relationships between final overbite and various patient and treatment characteristics, the studies were divided into three categories based on the long-term overbite ( $<3 \mathrm{~mm}, 3-4 \mathrm{~mm}$, and $>4 \mathrm{~mm}$ ). The mean values for sample size, posttreatment time, and initial and posttreatment overbite were calculated. Additionally, descriptive information was reported on molar classification, extractions, appliances, and retention. Greater initial posttreatment overbite revealed a tendency to be associated with greater longterm overbite (Table 3 ). These studies were also associated with more extractions, more functional appliance therapy, and less fixed retention. The length of follow-up did not indicate a clear pattern, with the deepest long-term overbite being associated with the shortest follow-up times.

Two studies reported on sectional versus continuous wire techniques [15,25]. Neither study reported major differences in the results of treatment or long-term stability of overbite correction. Two studies reported on correction in adolescent versus adult dentitions $[12,18]$. One of these studies suggested that adolescent treatment was slightly more stable, whereas the other study reported minimal differences. One study reported better stability of the curve of Spee with fixed rather than removable retainers [27].

Our aim was to assess patient and treatment parameters that were associated with stability of overbite. Most studies we identified were case series, with sampling methods that were not random or consecutive. Additionally, few studies used blinded assessment or adjustment for confounders. Some studies based inclusion on successful treatment, which might have resulted in optimistic reports of stability. Sample sizes tended to be small, and study designs and outcomes displayed considerable heterogeneity. Although two case series were judged at being low risk for bias, these types of studies are always susceptible to problems such as investigator bias, proficiency bias, reporting bias, and confounding by indication. For all these reasons, synthesizing information from the existing studies was challenging, and only descriptive statistics and stratified comparisons were reported, which must be interpreted with caution. Given these limitations, we present discussion of our results below. 


\subsection{Patient characteristics}

With respect to patient characteristics, it has been reported that pretreatment severity is correlated with long-term relapse of overbite [9]. To some extent, our systematic review would support this hypothesis because samples with greater pretreatment overbite displayed a tendency toward the deepest long-term overbite. However, it was difficult to isolate initial overbite from other confounding factors, such as amount of correction, type of appliances and retainers, and extractions.

One may ask if correction of deep bite during adolescence is more stable than correction after completion of growth. Two studies addressed this factor. Bock and Ruf [12] suggested adolescents may have greater stability than adults, but their samples were all relatively small ( $\leq 14$ patients in each subgroup). Harris [18], on the other hand, reported that stability was similar in adults and adolescents. It has been suggested that, on average, adolescents experience some reduction in overbite as they mature [46,57,58]. Berg et al. [59] also reported that the majority of untreated patients with deep bite exhibited less overbite when recalled many decades later. It is possible that the tendency for overbite to decrease during late adolescence might counteract the tendency for vertical relapse after orthodontic treatment. If so, this factor should be considered when comparing the stability of deep-bite correction in adults and adolescents. Additionally, the study by Pollard et al [24] suggests that patients with more divergent facial patterns exhibit less deepbite relapse [24].

Although our graphs illustrate a linear rate of relapse during the follow-up time, the data were only presented in that fashion because we did not have data for most studies at intermediate time points. The relapse may have occurred in first few years, which was suggested by a study measuring overbite at 2 and 5 years posttreatment [10]. The authors of this study reported that $80 \%$ of the total overbite relapse occurred during the first 2 years. Another study assessed overbite relapse at 5 and 11 years, and reported $0.5 \mathrm{~mm}$ change during the first 5 years, and $0.3 \mathrm{~mm}$ change in the next 6 years [26].

\subsection{Treatment characteristics}

Orthodontists generally agree that space-closing mechanics tend to deepen the bite, making it more difficult to correct and/or maintain the proper overbite relationship in patients with deep bite [60-63]. Although the heterogeneity of the studies precluded the performance of meta-analyses, we did not observe large differences based on the graphs we constructed. Several studies $[20,23,27,30]$ reported that extraction therapy is not contraindicated for deep bites and that stability was similar. However, three of these four studies used successful treatment as one of the inclusion criterion $[20,23,30]$, and this may have biased the studies towards more stable results.

Patients with Class II, Division 2 malocclusion are often associated with extremely severe overbite pretreatment. Many treatment factors may be associated with relapse in these patients, including extractions, change in incisor angulation, leveling techniques, maxillary incisor vertical position, and compliance with retention. Lapatki et al. [21, 22] reported that intruding maxillary incisors to avoid excessive contact with the lower lip lessens relapse in patients with Class II, Division 2 malocclusion. For all Class II patients, incomplete correction or relapse of the anteroposterior dimension may present an opportunity for incisors to over erupt, resulting in recurrence of a deep bite.

There is considerable debate on the advantages of sectional versus continuous archwire techniques for reducing deep bites. Those in favor of sectional wires claim that continuous wires may increase the mandibular plane angle, which will be prone to relapse, resulting in return of the deep bite [15]. Those in favor of continuous wires (with reverse curve of Spee) argue that intruding and proclining incisors with sectional wires will eventually result in 
vertical and angular relapse [15]. Only two of our included studies compared sectional versus continuous techniques, and interestingly, neither reported significant differences in the mechanism of correction or subsequent stability [15,25]. Other authors have compared different leveling techniques and have not found large differences in the mechanism of overbite correction, reporting that almost all techniques resulted in incisor intrusion and proclination [53].

Retention was an extremely challenging parameter to assess. About $25 \%$ of the studies did not describe the type of retainers used. The other $75 \%$ often reported the retainer type and regimen incompletely. Although the term "postretention" was used in many studies, its meaning was not always consistent. Some authors used this term to indicate the time period after treatment, whereas other authors used this term to indicate the time period after retainer use had been discontinued. A final challenge with the assessment of retention is our poor knowledge of patient compliance. A few studies reported that the majority of fixed retainers were in place at the time of the final follow-up visit $[12,13,16,22,27]$. This certainly could affect the relapse potential; Shannon and Nanda [27] reported that they found less curve of Spee relapse in their fixed retainer patients compared with their removable retainer patients at 2.8 years posttreatment. Because most of the included studies had follow-up times $>4$ years, retention may have been discontinued by then, especially when removable appliances were prescribed. If true, the impact of retainers may have been diminished in the longer studies because retainers would have been stopped well before the authors conducted their assessment of stability. As an example, Lapatki et al. [22] found that retention was associated with relapse in a study of patients 2 years posttreatment, but retention was not a factor when patients were assessed at 9 years [21]. Future studies should carefully report the retention methods employed, as well as whether any retainers are still in place or being used at the time of follow-up.

\subsection{Patient expectations and potential for harm}

In our experience, it is rare that patients request orthodontic treatment or re-treatment solely for the purpose of correcting a deep bite. In fact, patients often ask about the consequences if a deep bite is not corrected. For most patients, the risk for harm from a slight deep bite is probably minimal. However, for patients with deep bite with impingement on the palatal tissues, there is the potential for trauma and damage to the palatal tissues. Berg et al. [59] reported that $20 \%$ of patients with deep bite evaluated after a period of 57 years displayed some degree of palatal impingement.

\subsection{Future directions}

This systematic review might be considered a first step in addressing deep-bite stability because our inclusion criteria were fairly broad. Although it provides some overview of the topic, there are several limitations, in addition to the risk for bias that has already been mentioned. For example, the combining of data from many disparate sources may obscure true differences in stability that might be observed if we restricted our review to studies reporting on more homogeneous populations of patients or orthodontic treatments. Another potential limitation is that the mean values reported in studies might indicate relatively good overall stability, but on an individual basis, there certainly is the potential for significant relapse. For example, Ludwig [23] reported data for each patient, and about $15 \%$ of his sample displayed overbite measurements of $5+\mathrm{mm}$ long-term. The potential for confounding variables when assessing deep-bite stability is also challenging; this is depicted in Table 3, which shows potential relationships between initial severity, extractions, type of appliance, and retention. Addressing all these parameters in an individual study would require fairly large samples, possibly collected using a multi-site setting. Alternatively, future studies, as well as future reviews on the topic, may wish to restrict their scope to 
specific types of malocclusions and/or treatments in order to better manage these confounding variables.

\section{Conclusions}

In summary, we would judge the evidence on overbite correction and stability to be at significant risk for bias. However, based on the current body of literature that met our inclusion criteria, we found that patients with deep-bite malocclusion undergo considerable correction during treatment, and that most of the correction is maintained long-term. Initial severity appears to be related to long-term overbite. No large differences were observed for correction or stability in extraction versus nonextraction treatment. Although many techniques have been proposed regarding the optimal treatment for patients with deep bite, the few studies that addressed this issue found similar mechanisms of correction and longterm stability. Information on retention was rarely complete, making the impact of retention difficult to assess.

\section{Acknowledgments}

This study was supported in part by NIDCR Research Education and Training Grant R25 DE018436 (G.J.H., AM.B., S.S-H.C). The authors would like to thank Terry Ann Jankowski (Head Librarian, Information and Education Services, University of Washington Health Sciences Library, Seattle, WA) for her assistance with the search, as well as Dr. Thomas Flemmig (Professor, Department of Periodontics, University of Washington, Seattle, WA) for his assistance in translating articles.

\section{Appendix}

\section{Appendix A:}

\section{Appendix A}

Search Strategy

\begin{tabular}{|c|c|c|c|c|c|}
\hline \multicolumn{2}{|r|}{$\begin{array}{l}\text { Limits: Humans, Publication Date from 1966/01/01 to } \\
\text { 2012/06/27 }\end{array}$} & \multirow{2}{*}{$\begin{array}{r}\text { PubMed } \\
3476\end{array}$} & \multirow{2}{*}{$\begin{array}{r}\text { EMBASE } \\
1745\end{array}$} & \multirow{2}{*}{$\begin{array}{r}\text { Web of science } \\
11301\end{array}$} & \multirow{2}{*}{$\begin{array}{r}\text { Cochrane } \\
345\end{array}$} \\
\hline$\# 1$ & $\begin{array}{l}\text { deep-bite OR deep bite OR deepbite OR deep over- } \\
\text { bite OR deep over bite OR deep overbite } \\
\text { OR over-bite OR over bite OR overbite }\end{array}$ & & & & \\
\hline \#2 & imping* & 6381 & 5780 & 20856 & 313 \\
\hline$\# 3$ & $\begin{array}{l}\text { class } 2 \text { div* } 2 \text { OR class } 2 \text { div* II OR class II div* } 2 \\
\text { OR class II div* II }\end{array}$ & 920 & 7917 & 17,314 & 2763 \\
\hline \#4 & curve of spee & 124 & 9 & 90 & 5 \\
\hline \#5 & \#1 OR \#2 OR \#3 OR \#4 & 10739 & 15370 & 49351 & 3362 \\
\hline \#6 & retent* OR change* OR stable OR stabil* OR retain* & 1384958 & 1162023 & 3890517 & 140001 \\
\hline$\# 7$ & relapse OR recur* & 445522 & 375503 & 428400 & 38344 \\
\hline \#8 & $\begin{array}{l}\text { long-term OR longterm OR long term OR follow-up } \\
\text { OR followup OR follow up OR longitudinal }\end{array}$ & 1085432 & 1036360 & 1377757 & 134270 \\
\hline$\# 9$ & \#6 OR \#7 OR \#8 & 2523039 & 2231643 & 5216748 & 249217 \\
\hline$\# 10$ & orthodontics & 38463 & 2308 & 2704 & 1462 \\
\hline \multirow[t]{2}{*}{$\# 11$} & \#5 AND \#9 AND \#10 & 925 & 194 & 106 & 144 \\
\hline & Total & 1369 & & & \\
\hline
\end{tabular}




\section{Appendix B:}

\section{Appendix B}

\begin{tabular}{|c|c|c|c|}
\hline Study & Year & TITLE & Reason \\
\hline $\begin{array}{l}\text { Adenwalla and } \\
\text { Kronman [33] }\end{array}$ & 1985 & $\begin{array}{l}\text { Class II, division } 1 \text { treatment with Frankel and } \\
\text { Edgewise } \\
\text { appliances-a comparative study of } \\
\text { mandibular growth and facial esthetics }\end{array}$ & Not pertinent \\
\hline Al Yami, et al. [34] & 1999 & $\begin{array}{l}\text { Stability of orthodontic treatment outcome: } \\
\text { follow-up until } 10 \text { years } \\
\text { postretention }\end{array}$ & Not pertinent \\
\hline AlQabandi, et al. [35] & 1999 & $\begin{array}{l}\text { A comparison of the effects of rectangular and } \\
\text { round arch wires in leveling } \\
\text { the curve of Spee }\end{array}$ & No long-term follow-up \\
\hline $\begin{array}{l}\text { Bacetti, Franchi, et al. } \\
\text { [36] }\end{array}$ & 2011 & $\begin{array}{l}\text { Longitudinal growth changes in subjects with } \\
\text { deepbite }\end{array}$ & No comprehensive treatment \\
\hline Baima and Li [37] & 2007 & $\begin{array}{l}\text { Influence factors for long-term stability of } \\
\text { overbite correction. [Chinese] }\end{array}$ & Editorial/opinion paper \\
\hline Bantleon, et al. [38] & 1991 & $\begin{array}{l}\text { [Anterior tooth intrusion with the base arch: } \\
\text { preactivation by tip-back bending } \\
\text { or curvature?] }\end{array}$ & Editorial/opinion paper \\
\hline Bell, et al. [39] & 1984 & $\begin{array}{l}\text { Treatment of Class II deep bite by orthodontic } \\
\text { and surgical means }\end{array}$ & Editorial/opinion paper \\
\hline Bernstein, et al. [40] & 2007 & $\begin{array}{l}\text { Leveling the curve of Spee with a continuous } \\
\text { archwire technique: a long term } \\
\text { cephalometric study }\end{array}$ & No overbite data \\
\hline De Praeter, et al. [41] & 2002 & $\begin{array}{l}\text { Long-term stability of the leveling of the curve } \\
\text { of Spee }\end{array}$ & Not pertinent \\
\hline Devreese, et al. [42] & 2007 & $\begin{array}{l}\text { Stability of upper incisor inclination changes in } \\
\text { Class II division } 2 \text { patients }\end{array}$ & No overbite data \\
\hline $\begin{array}{l}\text { Edman-Tynelius, et al. } \\
\text { [43] }\end{array}$ & 2010 & $\begin{array}{l}\text { Evaluation of orthodontic treatment after } 1 \text { year } \\
\text { of retention-a randomized } \\
\text { controlled trial }\end{array}$ & Not limited to deep-bite patients \\
\hline Ferrazzini [44] & 2008 & $\begin{array}{l}\text { Class II/2 malocclusion: early treatment with } \\
\text { removable appliances and stability } \\
\text { after } 20 \text { years }\end{array}$ & No comprehensive treatment \\
\hline Fisk and McGaw [45] & 1980 & $\begin{array}{l}\text { Overbite changes concomitant with orthodontic } \\
\text { treatment }\end{array}$ & Not pertinent \\
\hline Franchi, et al. [46] & 2011 & $\begin{array}{l}\text { Outcomes of two-phase orthodontic treatment } \\
\text { of deepbite malocclusions }\end{array}$ & No overbite data (at T3) \\
\hline Gola [47] & 1975 & $\begin{array}{l}\text { [Conditions and stability factors in the therapy } \\
\text { for class II, division 2] }\end{array}$ & Unable to obtain \\
\hline Jager, et al. [48] & 1991 & $\begin{array}{l}\text { Longitudinal study of combined orthodontic } \\
\text { and surgical treatment of Class II } \\
\text { malocclusion with deep overbite }\end{array}$ & No comprehensive treatment \\
\hline Lie, et al. [49] & 2006 & $\begin{array}{l}\text { Post-treatment development of the curve of } \\
\text { Spee }\end{array}$ & No overbite data \\
\hline McCollum, et al. [50] & 1989 & $\begin{array}{l}\text { An alternative for the correction of the Class II } \\
\text { low mandibular plane angle }\end{array}$ & Number of patients $<15$ \\
\hline Miao and Liu [51] & 2002 & $\begin{array}{l}\text { Long-term stability of orthodontic treatment } \\
\text { out of retention }\end{array}$ & Not pertinent \\
\hline Millett, et al. [5] & 2006 & $\begin{array}{l}\text { Orthodontic treatment for deep bite and } \\
\text { retroclined upper front teeth } \\
\text { in children }\end{array}$ & Systematic review \\
\hline Noma [52] & 1983 & $\begin{array}{l}\text { A study on changes in the dental arch of } \\
\text { overbite patients resulting from } \\
\text { orthodontic treatment }\end{array}$ & Review article \\
\hline
\end{tabular}

J World Fed Orthod. Author manuscript; available in PMC 2013 September 01. 


\begin{tabular}{llll}
\hline Study & Year & TITLE & Reason \\
\hline Parker, et al. [53] & 1995 & $\begin{array}{l}\text { Skeletal and dental changes associated with the } \\
\text { treatment of deep bite } \\
\text { malocclusion }\end{array}$ & No long-term follow-up \\
$\begin{array}{l}\text { Ronnerman and Larsson } \\
\text { [54] } 1981\end{array}$ & $\begin{array}{l}\text { Overjet, overbite, intercanine distance and root } \\
\text { resorption in orthodontically } \\
\text { treated patients. A ten year follow-up study }\end{array}$ & Number of patients < 15 \\
Sondhi, et al. [55] & 1980 & $\begin{array}{l}\text { Dimensional changes in the dental arches of } \\
\text { orthodontically treated cases } \\
\text { [Correction of overbite by the edgewise }\end{array}$ & No overbite data \\
technic]
\end{tabular}

\section{References}

[1]. Jonsson T, Arnlaugsson S, Karlsson KO, Ragnarsson B, Arnarson EO, Magnusson TE. Orthodontic treatment experience and prevalence of malocclusion traits in an Icelandic adult population. Am J Orthod Dentofacial Orthop. 2007; 131:8.e11-8. [PubMed: 17208100]

[2]. Borzabadi-Farahani A, Eslamipour F. Malocclusion and occlusal traits in an urban Iranian population. An epidemiological study of 11- to 14-year-old children. Eur J Orthod. 2009; 31:477-84. [PubMed: 19477970]

[3]. Brunelle JA, Bhat M, Lipton JA. Prevalence and distribution of selected occlusal characteristics in the US population, 1988-1991. J Dent Res. 1996; 75:706-13. Spec No. [PubMed: 8594094]

[4]. Ng J, Major PW, Heo G, Flores-Mir C. True incisor intrusion attained during orthodontic treatment: a systematic review and meta-analysis. Am J Orthod Dentofacial Orthop. 2005; 128:212-9. [PubMed: 16102407]

[5]. Millett DT, Cunningham SJ, O'Brien KD, Benson P, Williams A, de Oliveira CM. Orthodontic treatment for deep bite and retroclined upper front teeth in children. Cochrane Database Syst Rev. 2006:CD005972. [PubMed: 17054268]

[6]. Al-Buraiki H, Sadowsky C, Schneider B. The effectiveness and long-term stability of overbite correction with incisor intrusion mechanics. Am J Orthod Dentofacial Orthop. 2005; 127:47-55. [PubMed: 15643414]

[7]. Artun J, Garol JD, Little RM. Long-term stability of mandibular incisors following successful treatment of Class II, Division 1, malocclusions. Angle Orthod. 1996; 66:229-38. [PubMed: 8805919]

[8]. Ball JV, Hunt NP. The effect of Andresen, Harvold, and Begg treatment on overbite and molar eruption. Eur J Orthod. 1991; 13:53-8. [PubMed: 2032568]

[9]. Berg R. Stability of deep overbite correction. Eur J Orthod. 1983; 5:75-83. [PubMed: 6572597]

[10]. Binda SK, Kuijpers-Jagtman AM, Maertens JK, van 't Hof MA. A long-term cephalometric evaluation of treated Class II division 2 malocclusions. Eur J Orthod. 1994; 16:301-8. [PubMed: 7957655]

[11]. Bishara SE, Chadha JM, Potter RB. Stability of intercanine width, overbite, and overjet correction. Am J Orthod. 1973; 63:588-95. [PubMed: 4513447]

[12]. Bock N, Ruf S. Post-treatment occlusal changes in Class II division 2 subjects treated with the Herbst appliance. Eur J Orthod. 2008; 30:606-13. [PubMed: 19054814]

[13]. Bondemark L, Kurol J. Class II correction with magnets and superelastic coils followed by straight-wire mechanotherapy. Occlusal changes during and after dental therapy. J Orofac Orthop. 1998; 59:127-38. [PubMed: 9639999]

[14]. Canut JA, Arias S. A long-term evaluation of treated Class II division 2 malocclusions: a retrospective study model analysis. Eur J Orthod. 1999; 21:377-86. [PubMed: 10502900]

[15]. Dake ML, Sinclair PM. A comparison of the Ricketts and Tweed-type arch leveling techniques. Am J Orthod Dentofacial Orthop. 1989; 95:72-8. [PubMed: 2910029]

[16]. Demisch A, Ingervall B, Thuer U. Mandibular displacement in Angle Class II, division 2 malocclusion. Am J Orthod Dentofacial Orthop. 1992; 102:509-18. [PubMed: 1456231] 
[17]. Dermaut LR. [Correction of sagittal overbite with a removable appliance: relative effects and various aspects of stability]. Rev Belge Med Dent. 1976; 31:101-22. [PubMed: 1066717]

[18]. Harris EF, Vaden JL. Posttreatment stability in adult and adolescent orthodontic patients: a cast analysis. Int J Adult Orthodon Orthognath Surg. 1994; 9:19-29. [PubMed: 8006479]

[19]. Hirschfelder U, Fleischer-Peters A. The functional treatment of deep bite-the results of a longterm study [article in German]. Fortschr Kieferorthop. 1992; 53:313-21. [PubMed: 1487215]

[20]. Kim TW, Little RM. Postretention assessment of deep overbite correction in Class II Division 2 malocclusion. Angle Orthod. 1999; 69:175-86. [PubMed: 10227559]

[21]. Lapatki BG, Baustert D, Schulte-Monting J, Frucht S, Jonas IE. Lip-to-incisor relationship and postorthodontic long-term stability of cover-bite treatment. Angle Orthod. 2006; 76:942-9. [PubMed: 17090163]

[22]. Lapatki BG, Klatt A, Schulte-Monting J, Stein S, Jonas IE. A retrospective cephalometric study for the quantitative assessment of relapse factors in cover-bite treatment. J Orofac Orthop. 2004; 65:475-88. [PubMed: 15570406]

[23]. Ludwig MK. An analysis of anterior overbite relationship changes during and following orthodontic treatment. Angle Orthod. 1966; 36:204-10. [PubMed: 5221252]

[24]. Pollard D, Akyalcin S, Wiltshire WA, Rody WJ Jr. Relapse of orthodontically corrected deepbites in accordance with growth pattern. Am J Orthod Dentofacial Orthop. 2012; 141:47783. [PubMed: 22464530]

[25]. Preston CB, Maggard MB, Lampasso J, Chalabi O. Long-term effectiveness of the continuous and the sectional archwire techniques in leveling the curve of Spee. Am J Orthod Dentofacial Orthop. 2008; 133:550-5. [PubMed: 18405819]

[26]. Schutz-Fransson U, Bjerklin K, Lindsten R. Long-term follow-up of orthodontically treated deep bite patients. Eur J Orthod. 2006; 28:503-12. [PubMed: 17000717]

[27]. Shannon KR, Nanda RS. Changes in the curve of Spee with treatment and at 2 years posttreatment. Am J Orthod Dentofacial Orthop. 2004; 125:589-96. [PubMed: 15127028]

[28]. Simons ME, Joondeph DR. Change in overbite: a ten-year postretention study. Am J Orthod. 1973; 64:349-67. [PubMed: 4521238]

[29]. Caracara S, Preston CB, Ossama J. The relationship between the curve of Spee, relapse, and the Alexander discipline. Semin Orthod. 2001; 7:90-9.

[30]. Magill JM. Changes in the anterior overbite relationship following orthodontic treatment in extraction cases. Am J Orthod. 1960; 46:755-88.

[31]. Sadowsky C, Schneider BJ, BeGole EA, Tahir E. Long-term stability after orthodontic treatment: nonextraction with prolonged retention. Am J Orthod Dentofacial Orthop. 1994; 106:243-9. [PubMed: 8074088]

[32]. Simons, ME. Change in overbite: a ten year postretention study. University of Washington; Seattle: 1971.

[33]. Adenwalla ST, Kronman JH. Class II, division 1 treatment with Frankel and Edgewise appliances-a comparative study of mandibular growth and facial esthetics. Angle Orthod. 1985; 55:281-98. [PubMed: 3865566]

[34]. Al Yami EA, Kuijpers-Jagtman AM, van 't Hof MA. Stability of orthodontic treatment outcome: follow-up until 10 years postretention. Am J Orthod Dentofacial Orthop. 1999; 115:300-4. [PubMed: 10066979]

[35]. AlQabandi AK, Sadowsky C, BeGole EA. A comparison of the effects of rectangular and round arch wires in leveling the curve of Spee. Am J Orthod Dentofacial Orthop. 1999; 116:522-9. [PubMed: 10547511]

[36]. Baccetti T, Franchi L, McNamara JA Jr. Longitudinal growth changes in subjects with deepbite. Am J Orthod Dentofacial Orthop. 2011; 140:202-9. [PubMed: 21803258]

[37]. Baima DJ, Li WR. Influence factors for long-term stability of overbite correction [article in Chinese]. Zhonghua Kou Qiang Yi Xue Za Zhi. 2007; 42:254-6. [PubMed: 17683681]

[38]. Bantleon HP, Weiland FJ, Droschl H. Anterior tooth intrusion with the base arch: preactivation by tip-back bending or curvature? [article in German]. Fortschr Kieferorthop. 1991; 52:153-8. [PubMed: 1894244] 
[39]. Bell WH, Jacobs JD, Legan HL. Treatment of Class II deep bite by orthodontic and surgical means. Am J Orthod. 1984; 85:1-20. [PubMed: 6581723]

[40]. Bernstein RL, Preston CB, Lampasso J. Leveling the curve of Spee with a continuous archwire technique: a long-term cephalometric study. Am J Orthod Dentofacial Orthop. 2007; 131:36371. [PubMed: 17346592]

[41]. De Praeter J, Dermaut L, Martens G, Kuijpers-Jagtman AM. Long-term stability of the leveling of the curve of Spee. Am J Orthod Dentofacial Orthop. 2002; 121:266-72. [PubMed: 11941340]

[42]. Devreese H, De Pauw G, Van Maele G, Kuijpers-Jagtman AM, Dermaut L. Stability of upper incisor inclination changes in Class II division 2 patients. Eur J Orthod. 2007; 29:314-20. [PubMed: 17483493]

[43]. Edman Tynelius G, Bondemark L, Lilja-Karlander E. Evaluation of orthodontic treatment after 1 year of retention-a randomized controlled trial. Eur J Orthod. 2010; 32:542-7. [PubMed: 20080961]

[44]. Ferrazzini G. Class II/2 malocclusion: early treatment with removable appliances and stability after 20 years. Schweiz Monatsschr Zahnmed. 2008; 118:814-9. [PubMed: 18846975]

[45]. Fisk RO, McGaw T. Overbite changes concomitant with orthodontic treatment. Ont Dent. 1980; 57:24-8. [PubMed: 6955724]

[46]. Franchi L, Baccetti T, Giuntini V, Masucci C, Vangelisti A, Defraia E. Outcomes of two-phase orthodontic treatment of deepbite malocclusions. Angle Orthod. 2011; 81:945-52. [PubMed: 21801005]

[47]. Gola L. Conditions and stability factors in the therapy for class II, division 2 [article in Italian]. Odontostomatol Implantoprotesi. Jul-Sep;1975 :41-2. [PubMed: 1088679]

[48]. Jager A, Kubein-Meesenburg D, Luhr HG. Longitudinal study of combined orthodontic and surgical treatment of Class II malocclusion with deep overbite. Int J Adult Orthodon Orthognath Surg. 1991; 6:29-38. [PubMed: 1940537]

[49]. Lie F, Kuitert R, Zentner A. Post-treatment development of the curve of Spee. Eur J Orthod. 2006; 28:262-8. [PubMed: 16495374]

[50]. McCollum AG, Reyneke JP, Wolford LM. An alternative for the correction of the Class II low mandibular plane angle. Oral Surg Oral Med Oral Pathol. 1989; 67:231-41. [PubMed: 2927916]

[51]. Miao Y, Liu C. Long-term stability of orthodontic treatment out of retention. Zhonghua Kou Qiang Yi Xue Za Zhi. 2002; 37:216-8. [PubMed: 12419149]

[52]. Noma S. A study on changes in the dental arch of overbite patients resulting from orthodontic treatment. J Nihon Univ Sch Dent. 1983; 25:200-1. [PubMed: 6580400]

[53]. Parker CD, Nanda RS, Currier GF. Skeletal and dental changes associated with the treatment of deep bite malocclusion. Am J Orthod Dentofacial Orthop. 1995; 107:382-93. [PubMed: 7709903]

[54]. Ronnerman A, Larsson E. Overjet, overbite, intercanine distance and root resorption in orthodontically treated patients. A ten year follow-up study. Swed Dent J. 1981; 5:21-7. [PubMed: 6943732]

[55]. Sondhi A, Cleall JF, BeGole EA. Dimensional changes in the dental arches of orthodontically treated cases. Am J Orthod. 1980; 77:60-74. [PubMed: 6928085]

[56]. Ulgen M, Altug Z. [Correction of overbite by the edgewise technic]. Fortschr Kieferorthop. 1987; 48:147-53. [PubMed: 3475235]

[57]. Bergersen EO. A longitudinal study of anterior vertical overbite from eight to twenty years of age. Angle Orthod. 1988; 58:237-56. [PubMed: 3189955]

[58]. Sinclair PM, Little RM. Maturation of untreated normal occlusions. Am J Orthod. 1983; 83:11423. [PubMed: 6572039]

[59]. Berg RE, Stenvik A, Espeland L. A 57-year follow-up study of occlusion. Part 2: oral health and attitudes to teeth among individuals with deep overbite at the age of 8 years. J Orofac Orthop. 2008; 69:309-24. [PubMed: 18797834]

[60]. Graber TM. Appliances at a crossroads. Am J Orthod. 1956; 42(9):683-701.

[61]. Cole HJ. Certain results of extraction in the treatment of malocclusion. Angle Orthod. 1948; 18:103-13. 
[62]. Heide M. Class II, division 2 - a challenge. Angle Orthod. 1957; 27:159-61.

[63]. Reid PV. A different approach to extraction. Am J Orthod. 1957; 43:334-65. 


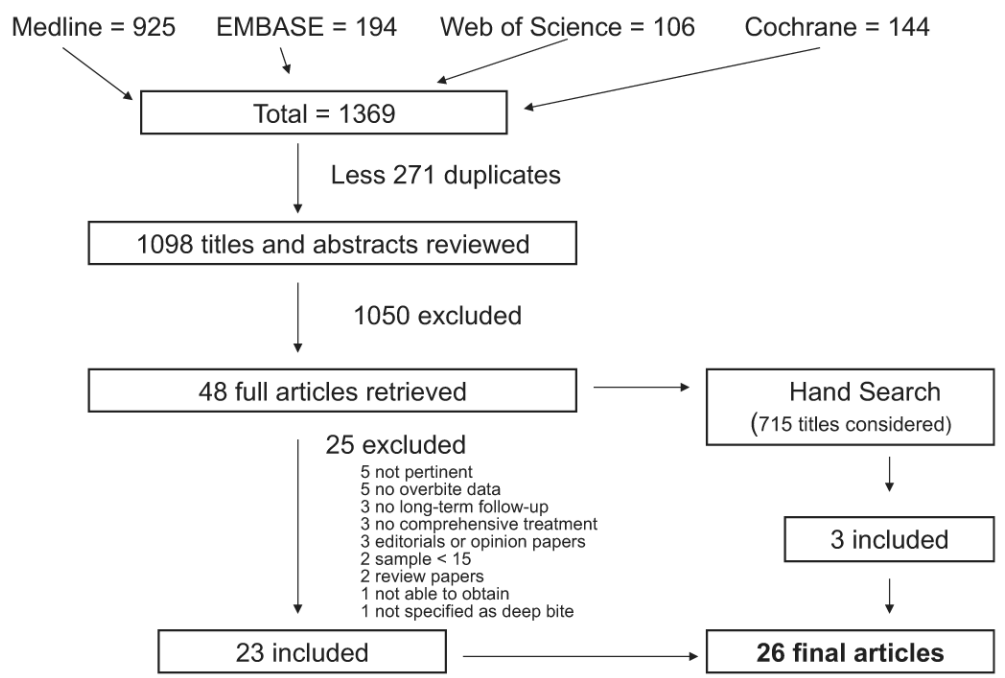

Fig. 1.

Flow diagram of literature search. 


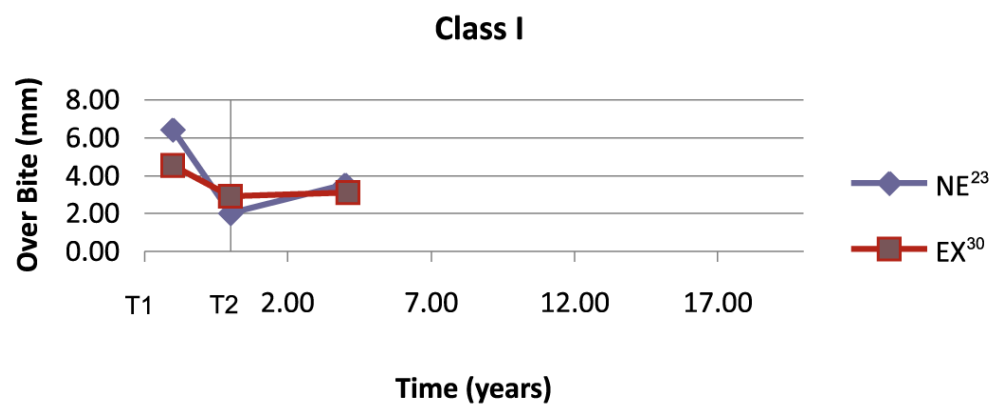

Fig. 2.

Class I studies: nonextractions (diamonds) [23] and extractions (squares) [30]. 


\section{Class II Div 1}

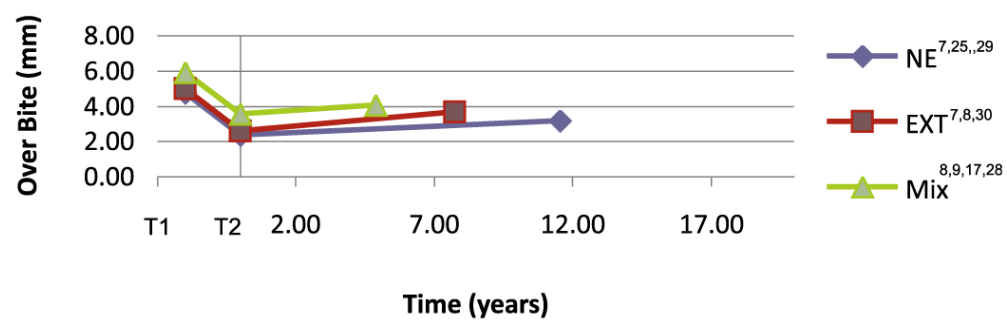

Fig. 3.

Class II, Division 1 studies: nonextractions (diamonds) [7,25,29], extractions (squares) $[7,8,30]$, and mixed (triangles) $[8,9,17,28]$. 
Class II Div 2

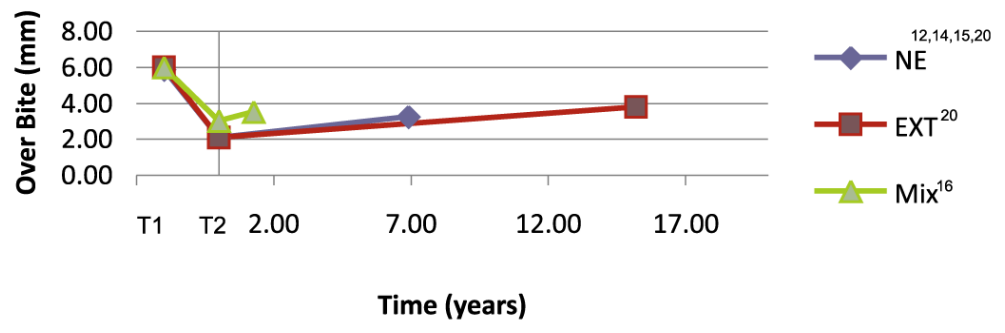

Fig. 4.

Class II, Division 2 studies: nonextractions (diamonds) [12,14,15,20], extractions (squares) [20], and mixed (triangles) [16]. 
Mixed Angle Classification

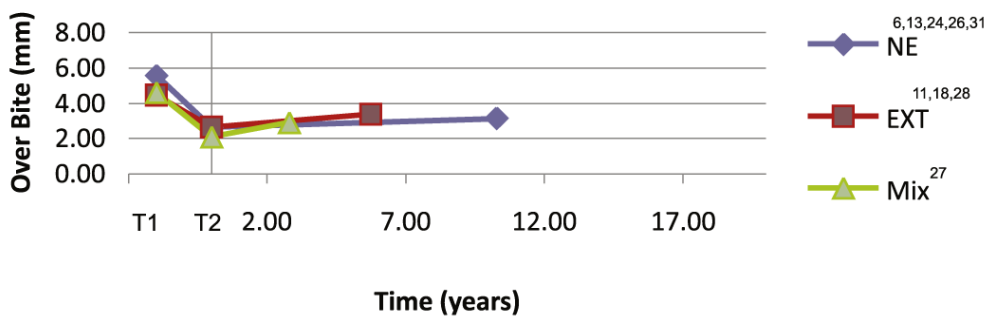

Fig. 5.

Mixed angle classification: nonextractions (diamonds) [5,13,24,26,31], extractions (squares) [11,18,28], and mixed (triangles) [27]. 


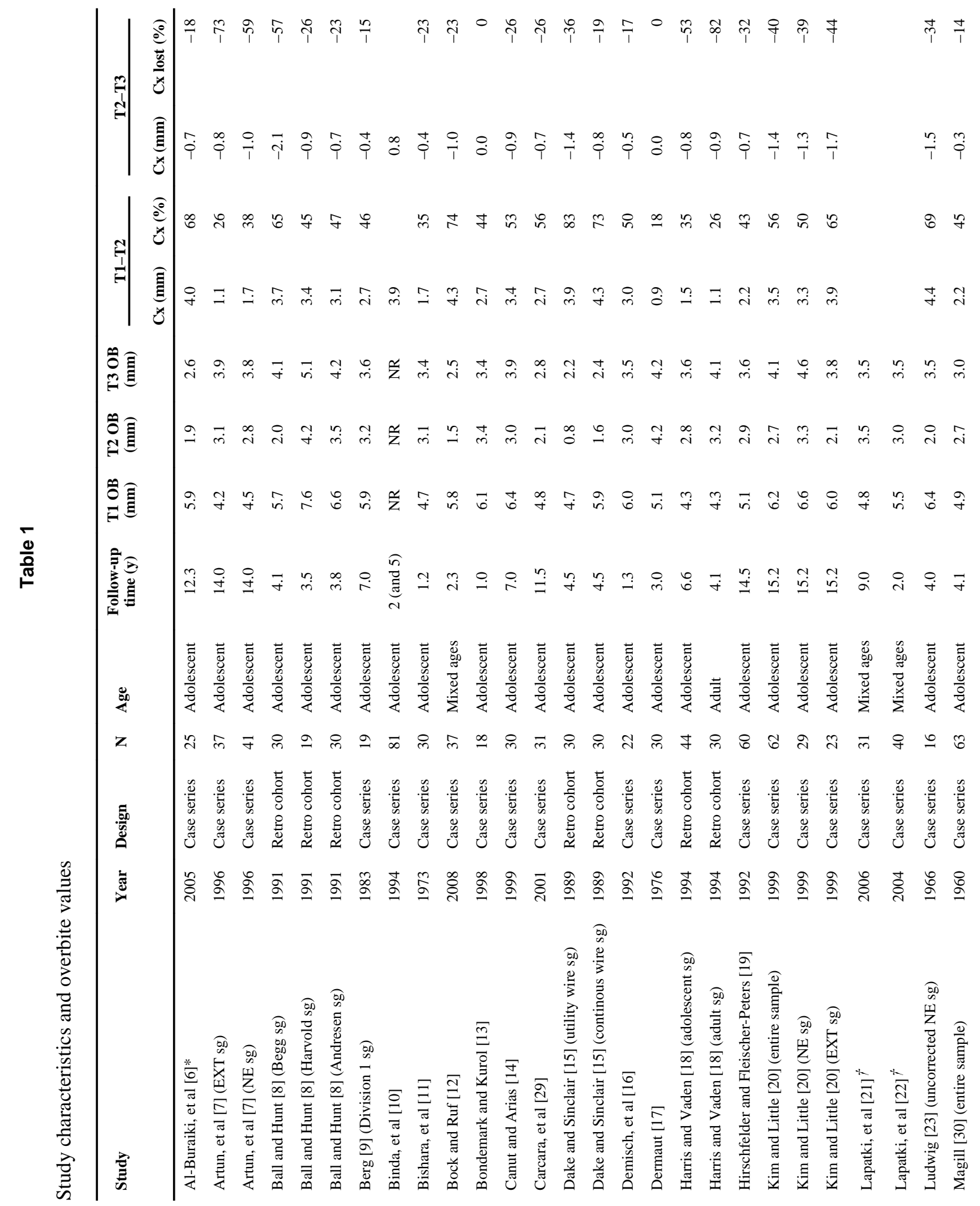




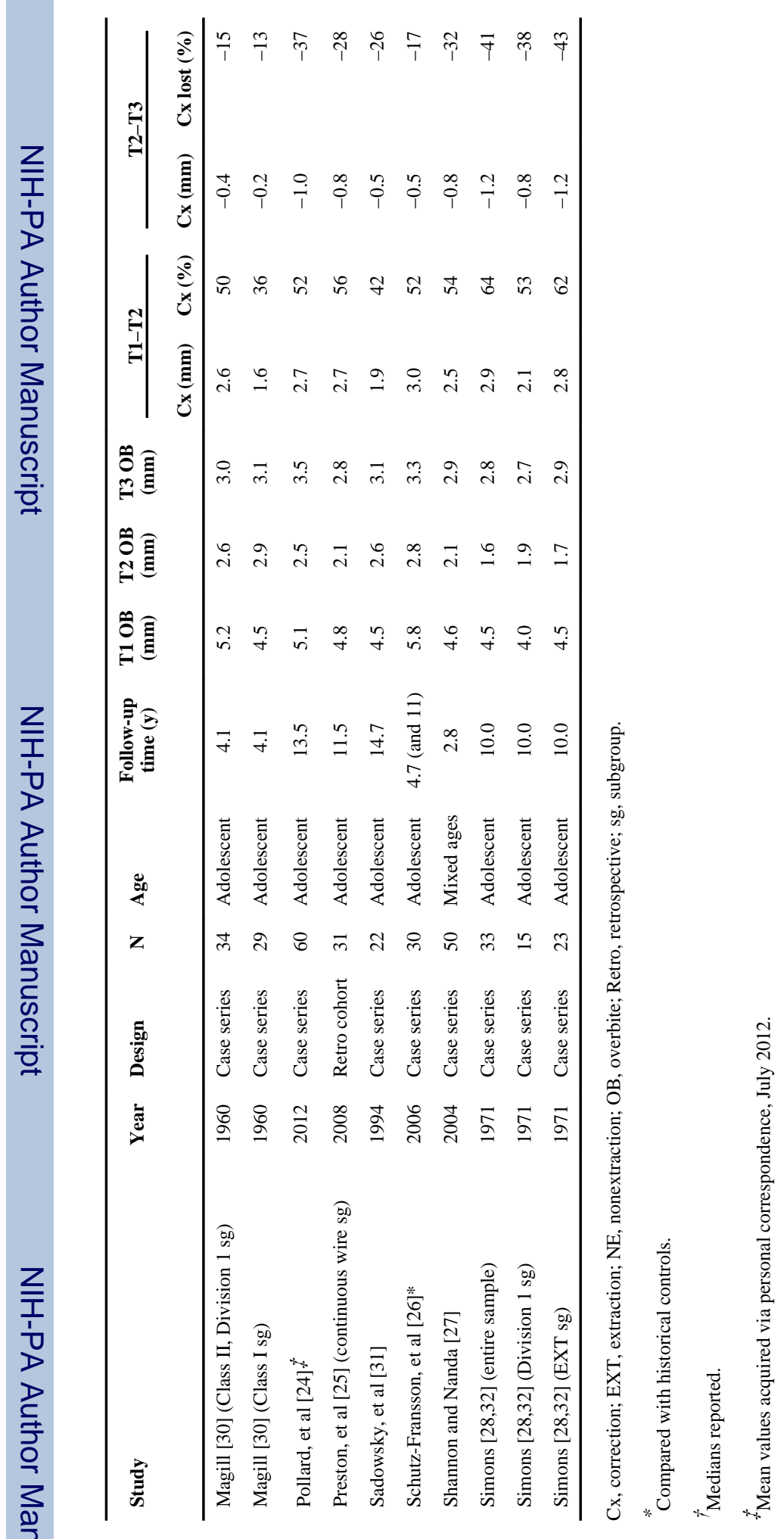


Table 2

Bias assessment

\begin{tabular}{|c|c|c|c|c|c|c|}
\hline Authors & IC specified & Sampling* & $\begin{array}{l}\text { Case series }{ }^{\dagger} \text { or } \\
\text { cohort study }\end{array}$ & Blinded assessment & Analyses & Total score ${ }^{\S}$ \\
\hline Al-Buraiki, et al [6] & Yes & Chosen by staff & No & NR & No & 1 \\
\hline Artun, et al [7] & Yes & Successful TX & Yes & NR & S & 3 \\
\hline Ball and Hunt [8] & Yes & No & No & NR & S & 2 \\
\hline Berg [9] & Yes & Good cooperation & No & NR & S & 2 \\
\hline Binda, et al [10] & Yes & No & Yes & NR & A & 3 \\
\hline Bishara, et al [11] & Yes & No & Yes & NR & No & 2 \\
\hline Bock and Ruf [12] & Yes & All meeting IC & Yes & Yes & S & 5 \\
\hline Bondemark and Kurol [13] & Yes & Consecutive & No & NR & No & 2 \\
\hline Canut and Arias [14] & Yes & No & Yes & NR & S & 3 \\
\hline Caracara, et al [29] & Yes & Random & Yes & Yes & MV & 5 \\
\hline Dake and Sinclair [15] & Yes & No & Yes & NR & No & 2 \\
\hline Demisch, et al [16] & Yes & No & No & NR & No & 1 \\
\hline Dermaut [17] & Yes & No & Yes & NR & No & 2 \\
\hline Harris and Vaden [18] & Yes & No & Yes & NR & No & 2 \\
\hline $\begin{array}{l}\text { Hirschfelder and Fleischer-Peters } \\
\text { [19] }\end{array}$ & Yes & No & Yes & NR & S & 3 \\
\hline Kim and Little [20] & Yes & Successful TX & Yes & NR & MV & 3 \\
\hline Lapatki, et al [21] & Yes & All willing patients & Yes & Randomized & MV & 4 \\
\hline Lapatki, et al [22] & Yes & No & Yes & NR & MV & 3 \\
\hline Ludwig [23] & Yes & Satisfactory TX & Yes & NR & S & 3 \\
\hline Magill [30] & Yes & Favorable results & Yes & NR & S & 3 \\
\hline Pollard [24] & Yes & Successful TX & Yes & NR & S & 3 \\
\hline Preston, et al [25] & Yes & Random & No & Yes & S & 4 \\
\hline Sadowsky, et al [31] & Yes & No & No & NR & No & 1 \\
\hline Schutz-Fransson, et al [26] & Yes & No & Yes & NR & S & 3 \\
\hline Shannon and Nanda [27] & Yes & No & Yes & NR & S & 3 \\
\hline $\begin{array}{l}\text { Simons and Joondeph [28], } \\
\text { Simons [32] }\end{array}$ & Yes & No & Yes & NR & S & 3 \\
\hline
\end{tabular}

A, ANOVA; IC, inclusion criteria; MV, multivariate; NR, not reported; S, stratified; TX, treatment.

* Sampling was random, consecutive, or all meeting IC.

$t_{30+\text { total. }}$

t30+ each group.

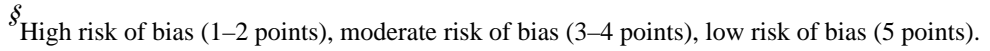


Table 3

Studies grouped by final overbite

\begin{tabular}{|c|c|c|c|c|c|c|c|c|c|}
\hline Study & $\mathbf{N}$ & Molar class & Extractions & Appliance & Retainers MX/MN & $\begin{array}{r}\text { Follow-up } \\
\text { time (y) }\end{array}$ & $\begin{array}{c}\text { T1 OB } \\
(\mathbf{m m})\end{array}$ & $\begin{array}{c}\text { T2 OB } \\
(\mathbf{m m})\end{array}$ & $\begin{array}{c}\text { T3 OB } \\
(\mathbf{m m})\end{array}$ \\
\hline Dake and Sinclair [15] & 30 & $\begin{array}{l}\text { Class II } \\
\text { (low MP) }\end{array}$ & No & Fixed (utility AW) & $\mathrm{R} / \mathrm{F}$ & 4.5 & 4.7 & 0.8 & 2.2 \\
\hline Dake and Sinclair [15] & 30 & $\begin{array}{l}\text { Class II } \\
\text { (low MP) }\end{array}$ & No & Fixed (continuous AW) & $\mathrm{R} / \mathrm{F}$ & 4.5 & 5.9 & 1.6 & 2.4 \\
\hline Bock and Ruf [12] & 37 & $\begin{array}{l}\text { Class II Div } \\
2\end{array}$ & No & Herbst + fixed & $\mathrm{R} /$ mixed & 2.3 & 5.8 & 1.5 & 2.5 \\
\hline Al-Buraiki, et al [6] & 25 & $\begin{array}{l}\text { Class I and } \\
\text { II }\end{array}$ & No & Fixed (sectional AW) & $\mathrm{R} / \mathrm{F}$ & 12.3 & 5.9 & 1.9 & 2.6 \\
\hline $\begin{array}{l}\text { Simons and Joondeph } \\
\text { [28], } \\
\quad \text { Simons [32] }\end{array}$ & 33 & $\begin{array}{l}\text { Class I and } \\
\text { II }\end{array}$ & Mix & Fixed & $\mathrm{R} / \mathrm{F}$ & 10.0 & 4.5 & 1.6 & 2.8 \\
\hline Caracara, et al [29] & 31 & $\begin{array}{l}\text { Class II Div } \\
1\end{array}$ & No & Fixed (continuous AW) & $N R / F$ & 11.5 & 4.8 & 2.1 & 2.8 \\
\hline Preston, et al [25] & 31 & $\begin{array}{l}\text { Class II Div } \\
1\end{array}$ & No & Fixed (continuous AW) & $N R / F$ & 11.5 & 4.8 & 2.1 & 2.8 \\
\hline $\begin{array}{l}\text { Shannon and Nanda } \\
\text { [27] }\end{array}$ & 50 & $\begin{array}{l}\text { Class I and } \\
\text { II }\end{array}$ & Mix & Fixed & Mixed & 2.8 & 4.6 & 2.1 & 2.9 \\
\hline Mean or summary & 33.4 & 3/8 Class I & 2/8 Extractions & 0/8 Functional only & 6/8 Fixed MN & 7.4 & 5.1 & 1.7 & 2.6 \\
\hline Magill [30] & 63 & $\begin{array}{l}\text { Class I and } \\
\text { II Div } 1\end{array}$ & Yes & Fixed & NR & 4.1 & 4.9 & 2.7 & 3.0 \\
\hline Sadowsky, et al [31] & 22 & $\begin{array}{l}\text { Class I and } \\
\text { II }\end{array}$ & No & Fixed & $\mathrm{R} / \mathrm{F}$ & 14.7 & 4.5 & 2.6 & 3.1 \\
\hline $\begin{array}{l}\text { Schutz-Fransson, et al } \\
\text { [26] }\end{array}$ & 30 & $\begin{array}{l}\text { Class I and } \\
\text { II }\end{array}$ & No & Fixed or functional & $\mathrm{R} / \mathrm{F}$ & 4.7 & 5.8 & 2.8 & 3.3 \\
\hline $\begin{array}{l}\text { Bondemark and Kurol } \\
\text { [13] }\end{array}$ & 18 & Class II & No & $\begin{array}{l}\text { Coil or magnet + fixed } \\
\text { R/NR }\end{array}$ & & 1.0 & 6.1 & 3.4 & 3.4 \\
\hline Bishara, et al [11] & 30 & NR & Yes & Fixed & NR & 1.2 & 4.7 & 3.1 & 3.4 \\
\hline Demisch, et al [16] & 22 & $\begin{array}{l}\text { Class II Div } \\
2\end{array}$ & NR & Functional & $\mathrm{R}$ & 1.3 & 6.0 & 3.0 & 3.5 \\
\hline Pollard, et al [24] & 60 & $\begin{array}{l}\text { Class I, II, } \\
\text { and III }\end{array}$ & No & Fixed & $\mathrm{R} / \mathrm{R}$ or $\mathrm{F}$ & 13.5 & 5.1 & 2.5 & 3.5 \\
\hline Ludwig [23] & 16 & Class I & Mix & Fixed & NR & 4.0 & 6.4 & 2.0 & 3.5 \\
\hline Berg [9] & 19 & $\begin{array}{l}\text { Class II Div } \\
1\end{array}$ & Mix & Fixed & NR & 7.0 & 5.9 & 3.2 & 3.6 \\
\hline Harris and Vaden [18] & 44 & $\begin{array}{l}\text { Class I and } \\
\text { II }\end{array}$ & Yes & Fixed & $\mathrm{R}$ & 6.6 & 4.3 & 2.8 & 3.6 \\
\hline $\begin{array}{l}\text { Hirschfelder and } \\
\text { Fleischer-Peters [19] }\end{array}$ & 60 & $\begin{array}{l}\text { Class I and } \\
\text { II }\end{array}$ & NR & Functional & NR & 14.5 & 5.1 & 2.9 & 3.6 \\
\hline Artun, et al $[7]^{*}$ & 41 & $\begin{array}{l}\text { Class II Div } \\
1\end{array}$ & No & Fixed & $\mathrm{R} / \mathrm{F}$ & 14.0 & 4.5 & 2.8 & 3.8 \\
\hline Kim and Little [20] ${ }^{*}$ & 23 & $\begin{array}{l}\text { Class II Div } \\
2\end{array}$ & No & Fixed & $\mathrm{R} / \mathrm{F}$ & 15.2 & 6.0 & 2.1 & 3.8 \\
\hline Artun, et al [7] ${ }^{*}$ & 37 & $\begin{array}{l}\text { Class II Div } \\
1\end{array}$ & Yes & Fixed & $\mathrm{R} / \mathrm{F}$ & 14.0 & 4.2 & 3.1 & 3.9 \\
\hline Canut and Arias [14] & 30 & $\begin{array}{l}\text { Class II Div } \\
2\end{array}$ & No & Fixed & NR & 7.0 & 6.4 & 3.0 & 3.9 \\
\hline Mean or summary & 34.3 & 6/15 Class I & 6/13 Extractions & 2/15 Functional only & 5/9 Fixed MN & 8.2 & 5.3 & 2.8 & 3.5 \\
\hline
\end{tabular}




\begin{tabular}{|c|c|c|c|c|c|c|c|c|c|}
\hline Study & $\mathbf{N}$ & Molar class & Extractions & Appliance & Retainers MX/MN & $\begin{array}{r}\text { Follow-up } \\
\text { time }(y)\end{array}$ & $\begin{array}{c}\text { T1 OB } \\
(\mathrm{mm})\end{array}$ & $\begin{array}{c}\text { T2 OB } \\
(\mathrm{mm})\end{array}$ & $\begin{array}{c}\text { T3 OB } \\
(\mathrm{mm})\end{array}$ \\
\hline Ball and Hunt [8] & 30 & $\begin{array}{l}\text { Class II Div } \\
1\end{array}$ & Yes & Begg & $\mathrm{R} / \mathrm{NR}$ & 4.1 & 5.7 & 2.0 & 4.1 \\
\hline Harris and Vaden [18] & 30 & $\begin{array}{l}\text { Class I and } \\
\text { II }\end{array}$ & Yes & Fixed & $\mathrm{R}$ & 4.1 & 4.3 & 3.2 & 4.1 \\
\hline Ball and Hunt [8] & 30 & $\begin{array}{l}\text { Class II Div } \\
1\end{array}$ & NR & Andresen & $\mathrm{R} / \mathrm{NR}$ & 3.8 & 6.6 & 3.5 & 4.2 \\
\hline Dermaut [17] & 30 & $\begin{array}{l}\text { Class II Div } \\
1\end{array}$ & Mix & Removable & $\mathrm{R}$ & 3.0 & 5.1 & 4.2 & 4.2 \\
\hline Kim and Little [20] & 29 & $\begin{array}{l}\text { Class II Div } \\
2\end{array}$ & Yes & Fixed & $\mathrm{R} / \mathrm{F}$ & 15.2 & 6.6 & 3.3 & 4.6 \\
\hline Ball and Hunt [8] & 19 & $\begin{array}{l}\text { Class II Div } \\
1\end{array}$ & NR & Harvold & $\mathrm{R} / \mathrm{NR}$ & 3.5 & 7.6 & 4.2 & 5.1 \\
\hline Mean or summary & 28.0 & 1/6 Class I & 4/4 Extractions & 3/6 Removable only & 1/3 Fixed MN & 5.6 & 6.0 & 3.4 & 4.4 \\
\hline
\end{tabular}

AW, archwire; F, fixed retainer; MN, mandibular arch; MP, mandibular plane; MX, maxillary arch; NR, not reported; OB, overbite; R = removable.

Retention verified via personal correspondence, May 2011. 